\title{
Climate change influences on abundance, individual size and body abnormalities in a sandy beach clam
}

\author{
Leonardo Ortega ${ }^{1}$, Eleonora Celentano ${ }^{2}$, Estela Delgado ${ }^{3}$, Omar Defeo ${ }^{1,2,4, *}$ \\ ${ }^{1}$ DINARA, Constituyente 1497, 11200 Montevideo, Uruguay \\ ${ }^{2}$ UNDECIMAR, Facultad de Ciencias, Iguá 4225, CP 11400, Montevideo, Uruguay \\ ${ }^{3}$ Centro Universitario de la Región Este, Maldonado, Uruguay \\ ${ }^{4}$ GEPEIA, Centro Universitario de la Región Este, Rocha, Uruguay
}

\begin{abstract}
Sandy beaches are being threatened by a changing climate. However, the effects of this changing environment, including warming, on these ecosystems, have hitherto been tentative and qualitative. Using concurrent long-term (1984-2007) observations on abundance and individual size, together with laboratory examinations of body abnormalities (morphological anomalies and epibionts), we provide evidence that the sandy beach yellow clam Mesodesma mactroides of the Uruguayan coast has responded to climate change. Regional sea surface temperature anomalies (SSTA) showed an increasing trend through time, with positive values after 1997. The position of the warm water front $\left(20^{\circ} \mathrm{C}\right.$ isotherm $)$, a proxy of tropical waters, showed a long-term poleward shift rate of ca. $9 \mathrm{~km} \mathrm{yr}^{-1}$. Clam abundance (total and discriminated by population component) decreased through time and was inversely related to variations in SSTA, with higher abundance during cold periods. Length frequency distributions (LFDs) showed polymodal size structures with fully represented clam population components in cool years. By contrast, LFDs showed fewer size classes and larger clams were virtually absent during warm years. Prevalence of body abnormalities in $M$. mactroides increased through time and was positively correlated with increasing SSTA, suggesting a link with climate stress. The population dynamics of $M$. mactroides seems to be driven by climatic forcing, mostly related with warming. Our results demonstrate the implications of climate change in the structure of sandy beach fauna, which could be particularly relevant in ectotherms with cold water affinities. Thus, climate change should be given a high priority in sandy beach conservation planning and management.
\end{abstract}

KEY WORDS: Sandy beaches · Macrofauna - Ocean warming $\cdot$ Mass mortality $\cdot$ Population traits · Yellow clam $\cdot$ Mesodesma mactroides $\cdot$ Uruguay

\section{INTRODUCTION}

Sandy beaches are among the most valuable and heavily used natural coastal systems worldwide and provide critical ecosystem services to society, including shoreline protection, food from fisheries and economic revenues from tourism (Schlacher et al. 2008, Defeo et al. 2009). However, the world's shorelines are being threatened by the combined effect of increasing human impacts due to an expanding population and increasing demand for food and leisure

\footnotetext{
${ }^{*}$ Corresponding author: odefeo@dinara.gub.uy
}

and the rising sea level resulting from a changing climate (Doney et al. 2012, McLachlan et al. 2013). Effects of climate change may be most immediately and profoundly felt in sandy beach macrofauna (Ortega et al. 2012, Schoeman et al. 2014). Its narrow physical habitat is being disrupted rapidly as a result of erosion caused by sea-level rise and intensification of storms (Schlacher et al. 2007, Defeo et al. 2009, Dugan et al. 2010, Ortega et al. 2013).

The direct effects of a changing environment, including warming, could enhance disease expres-

() The authors 2016. Open Access under Creative Commons by Attribution Licence. Use, distribution and reproduction are unrestricted. Authors and original publication must be credited. 
sion (Harvell et al. 2002, Kordas et al. 2011, Maynard et al. 2015) and pathogen abundance (Burreson \& Ragone Calvo 1996, Ford \& Tripp 1996, Parmesan \& Yohe 2003, Nye et al. 2009, Baker-Austin et al. 2013) in marine populations. Therefore, climate change, notably increasing temperatures, could drive hostpathogen interactions and infectious disease outbreaks (Loreau et al. 2005), as well as worsening host body condition (Riascos et al. 2009a). Climate change has already increased the occurrence of diseases, particularly in ectothermic organisms such as shellfish (Travers et al. 2009), corals (Harvell et al. 2002) and finfish (Bowden 2008). Thus, preserving the health of these ecosystems requires assessing the effects of such stressors concurrently with climate change. However, these impacts are less clearly linked to sandy beach species.

The genus Mesodesma inhabits Pacific and Atlantic sandy beaches of South America. It has an Antarctic origin and can be associated with cold water systems (von Ihering 1907). The genus invaded South America in the late Pliocene/early Pleistocene, and the migration was probably triggered by decreasing temperatures at the end of the Tertiary and early Quaternary periods (von Ihering 1907, Marins \& Levy 1999, Uribe et al. 2012). The yellow clam Mesodesma mactroides Reeve, 1854 inhabits the intertidal of dissipative sandy beaches from Río de Janeiro (Brazil, $24^{\circ} \mathrm{S}$ ) to Golfo San Matías (Argentina, $\left.41^{\circ} \mathrm{S}\right)$ in the Southwestern Atlantic Ocean (SAO) (Fiori \& Defeo 2006). This fast-growing, shortlived species $(<4 \mathrm{yr})$ is a suspension feeder with a high fecundity, producing about 5 million eggs per female (Defeo et al. 1992b). Gonadal development is controlled by temperature, with spawning taking place when the temperature is close to $20^{\circ} \mathrm{C}$ (McLachlan et al. 1996). This species is artisanally exploited and the fishery is governed by a co-management mode and a set of operational precautionary measures that maintain low fishing pressure levels (Gianelli et al. 2015). During the last 20 yr, mass mortality events decimated yellow clam populations along thousands of $\mathrm{km}$ of sandy beaches in Brazil, Uruguay and Argentina, particularly during the warm seasons (Odebrecht et al. 1995, Fiori \& Cazzaniga 1999, Defeo et al. 2013). Various pathogens have been noted as potential causative factors of these mass mortalities, including meront stages of coccidians in the intestine, gills and stomach (Fiori et al. 2004), Trichodina sp. ciliates, gregarines and turbellarians (Cremonte \& Figueras 2004, Cremonte et al. 2005) and the endoparasite Paravortex mesodesma (Brusa et al. 2006). However, mass mortality events still remain unexplained, and the potential concurrent effects of warming temperatures and pathogens on yellow clam populations have not been addressed.

In this paper we evaluate the role of climate change in explaining long-term fluctuations in abundance, individual size, and body abnormalities (including morphological anomalies and epibionts) in the yellow clam $M$. mactroides inhabiting sandy beaches of Uruguay in the SAO. To this end, we followed a hypothetico-deductive method to construct explanatory hypotheses and predictions under climate change expectations (sensu Schoeman et al. 2014). Taking into account the systematic increase in sea surface temperature (SST) observed over the past 3 decades across the SAO (Ortega et al. 2012) and the Antarctic origin of $M$. mactroides, we predict a long-term decrease in population abundance and individual size, concurrently with increasing signs of deteriorating body condition.

\section{MATERIALS AND METHODS}

\section{Study area and environmental settings}

The study was conducted in Barra del Chuy $\left(33^{\circ} 45^{\prime} \mathrm{S}, 53^{\circ} 27^{\prime} \mathrm{W}\right)$, an exposed microtidal (tidal range: $0.5 \mathrm{~m}$ ) oceanic sandy beach of Uruguay (Fig. 1). It is a wide dissipative beach (mean width \pm SD: $69 \pm 12 \mathrm{~m})$ with a gentle slope $(2.9 \pm 0.5 \%)$, fine to very fine sands $(0.20 \pm 0.03 \mathrm{~mm})$, and a wide surf zone of a longshore-bar-trough type (Ortega et al. 2013). This sandy beach harbors the highest macrofaunal richness, abundance and biomass on the Uruguayan coast (Lercari \& Defeo 2006, 2015). In terms of biomass, the beach/surf community is dominated by yellow clams (Defeo et al. 1992a).

Sea surface temperature anomalies (SSTA) were obtained from the dataset NOAA NCEP EMC CMB GLOBAL Reyn_SmithOIv2 monthly SSTA (IRI/LDEO Climate Data Library; Reynolds et al. 2002). The climatological base period used to calculate SSTA was 1971-2000, and the base period used for the standardization is from November 1981 to present. Standardized SSTA was calculated by dividing monthly mean values by each standard deviation. Then, these values were regionally averaged (SSTA from $4^{\circ} \times 3^{\circ}$ grid cells: Fig. 1) using the Ingrid language utilities provided by IRI. Regional average of standardized SSTA was used as regional climate index to describe longterm trends and their variability in the state of the ocean climate. Tropical Water in the SAO is defined 
by temperatures $>20^{\circ} \mathrm{C}$ and salinities $>36$, and is carried southward by the Brazil Current (Emilson 1961, Thomsen 1962). Thus, we tracked latitudinal variations of the $20^{\circ} \mathrm{C}$ isotherm as a proxy of the latitudinal shift of the Tropical Water front. The latitudinal position of this warm water front in each month was digitized. Isotherm tracking was computed from monthly SST satellite images with $9 \mathrm{~km}$ resolution (AVHRR Pathfinder from 1985-2003 (http://podaac-www.jpl. nasa.gov/) and Aqua MODIS (http://oceancolor.gsfc. nasa.gov/) from 2004-2007). Monthly regional SST was extracted with the SeaWiFS Data Analysis System (SeaDAS: http://seadas.gsfc.nasa.gov/) and the geostatistical method of Kriging was used to build the grid and plot the isotherms. Both satellite data sources were used to cover the time frame used in our paper. The time series of SSTA and the latitudinal position of the warm water front were decomposed into their classic components (seasonal, trend and remainder) using the LOESS method (local polynomial regression) included in $\mathrm{R}$ statistical software ( $\mathrm{R}$ Development Core Team 2008). The resulting information of both variables was used to model long-term trends of biological variables. The cumulative sum of the annual trend of SSTA (SSTAcs) was used to detect sustained shifts in climate, marked by changes in slope of the cumulative sum plot (Fiedler 2002 and references therein).

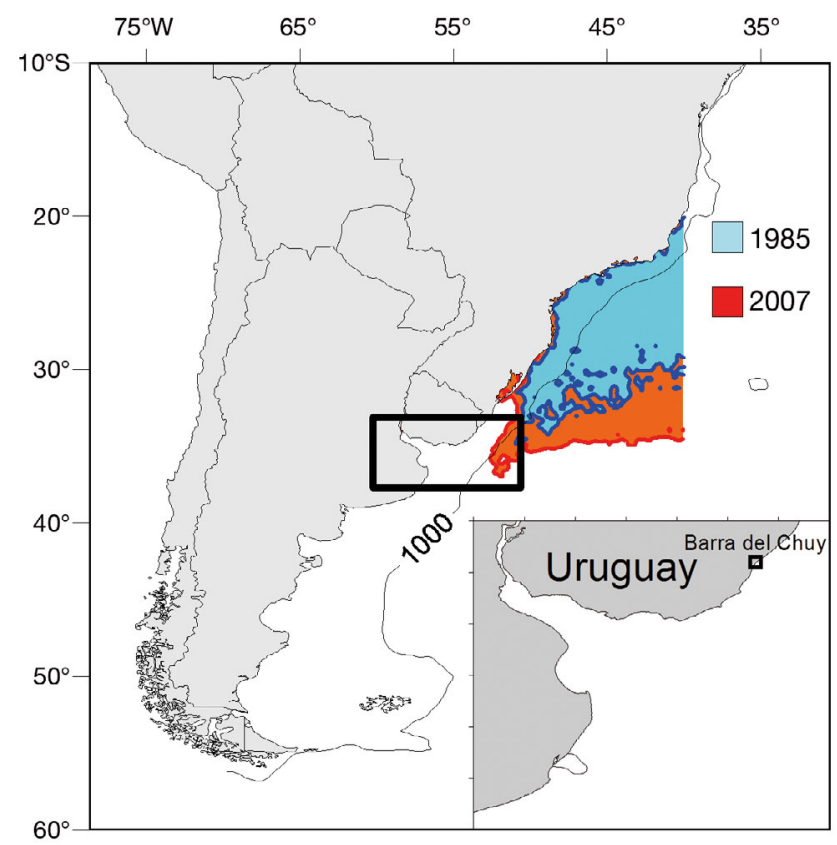

Fig. 1. Study area, showing the location of Barra del Chuy in Uruguay and the contour lines of the mean annual position of the $20^{\circ} \mathrm{C}$ isotherm derived from sea surface temperatures recorded at the beginning (1985) and at the end (2007) of the study period (see 'Materials and methods' for details)

\section{Sampling design, laboratory and data analyses}

Long-term yellow clam surveys were conducted in 9 years between 1984 and 2007 (1984, 1988, 1989, 1996, 1999 and 2004-2007) at Barra del Chuy beach. In each year the yellow clam was sampled seasonally (at least 4 times a year) along 22 equidistant transects perpendicular to the shoreline. Sampling units (SUs) on each transect were taken every $4 \mathrm{~m}$ with a $27 \mathrm{~cm}$ diameter cylinder and $40 \mathrm{~cm}$ deep, from the base of the dunes to the lower limit of the swash zone, until at least 2 consecutive SUs yielded no clams (i.e. species-driven sampling design, sensu Defeo \& Rueda 2002). The sand from each SU was sieved through a $0.5 \mathrm{~mm}$ mesh and the clams retained from these surveys were preserved in $10 \%$ buffered formaldehyde in seawater. The total length of each clam was measured to the nearest $0.01 \mathrm{~mm}$ with a caliper. Yellow clam abundance was estimated through the number per strip transect (IST, ind. $\mathrm{m}^{-1}$; Defeo 1996) for the total population (i.e. all size classes ranging from 1 to $76 \mathrm{~mm}$ ), as well as for recruits (ind. $<10 \mathrm{~mm}$ ) and adults (ind. $>43 \mathrm{~mm}$, i.e. the mean size at maturity; Masello \& Defeo 1986). Abundance of recruits was calculated only for the recruitment period, which occurs during the austral summer season (Defeo et al. 1992b, Defeo 1998). Annual length frequency distributions (LFDs) of the yellow clam population were grouped into $4 \mathrm{~mm}$ size classes. The index of recurrence of size classes (IRSC; Celentano et al. 2010) was calculated as IRSC $=\mathrm{N}_{\mathrm{y}} / \mathrm{N}_{\mathrm{t}}$ where $\mathrm{N}_{\mathrm{y}}$ defines the number $(\mathrm{N})$ of size classes in a given year $(\mathrm{y})$ and $\mathrm{N}_{\mathrm{t}}$ is the total number of size classes of Mesodesma mactroides observed in all years analyzed. IRSC ranges between 0 and 1 (all size classes present). An annual weighted mean individual size was estimated as the product of the mean individual size for a given year and the corresponding IRSC estimate.

Live and well-preserved clams collected during surveys were used to assess body abnormalities, which included morphological anomalies in foot (weak muscular areas and malformations) and gills (lesions and differential thickening), as well as epibiont load on clam valves. The mean percentage of morphological abnormalities and epibiont load (data pooled) was used as an indicator of overall body condition (body abnormalities). A total of 1861 yellow clams were examined under a binocular microscope. Eggs of epibionts used for species identification were excysted spontaneously by exerting pressure on them. The emerged animals were analyzed under light microscopy in squeeze preparations and photographed. Epibiont prevalence was estimated as the ratio between the num- 
ber of infested clams and the total number of clams examined (Margolis et al. 1982). Long-term variations in SSTA, latitudinal position of the warm water front, abundance, individual size, and body abnormalities were modelled by linear or nonlinear fitting procedures to assess upward or downward trends over time, as well between them. The best model was selected using $\mathrm{R}^{2}$ and the corresponding F-tests. Taking into account the empirical evidence and the theoretical framework detailed in the Introduction, the following hypotheses were assessed: (1) SST increased towards higher latitudes over time; (2) abundance and individual size decreased over time, and (3) body abnormalities increased over time, in both cases concurrently with increasing SST.

\section{RESULTS}

\section{First prediction: temperature increased towards higher latitudes}

Regional SSTA showed an increasing trend during the analyzed period, with a clear dominance of positive values after 1997 (Fig. 2a). The position of the warm water front, a proxy of the front of tropical waters, showed a consistent long-term poleward shift trend that increased linearly through time (Fig. $2 \mathrm{~b})$, despite the cyclic variation and the occurrence of 2 cold years (1988 and 1999). A southward shift rate of ca. $9 \mathrm{~km} \mathrm{yr}^{-1}$ of the $20^{\circ} \mathrm{C}$ isotherm was estimated for the study period (Fig. 2b). This trend was consistent with the increase of SSTA, and thus both variables were positively and significantly correlated (Fig. 2c). The decomposition performed by time series analyses showed a clear seasonal pattern in SSTA and the latitudinal position of the warm water front, with a seasonal increase in SSTA after the late 1990s and a regular seasonality in the latitudinal position of the warm water front (Fig. S1 in the Supplement at www.int-res.com/articles/suppl/ m545p203_supp.pdf).

\section{Second prediction: abundance and individual size decreased over time, concurrently with increasing temperatures}

Total abundance of $M$. mactroides markedly decreased between 1984 and 2007, showing higher abundances during the cool period than in the warmer one (Fig. 3a). These 2 periods were differentiated by a marked change in the slope of the cumu-
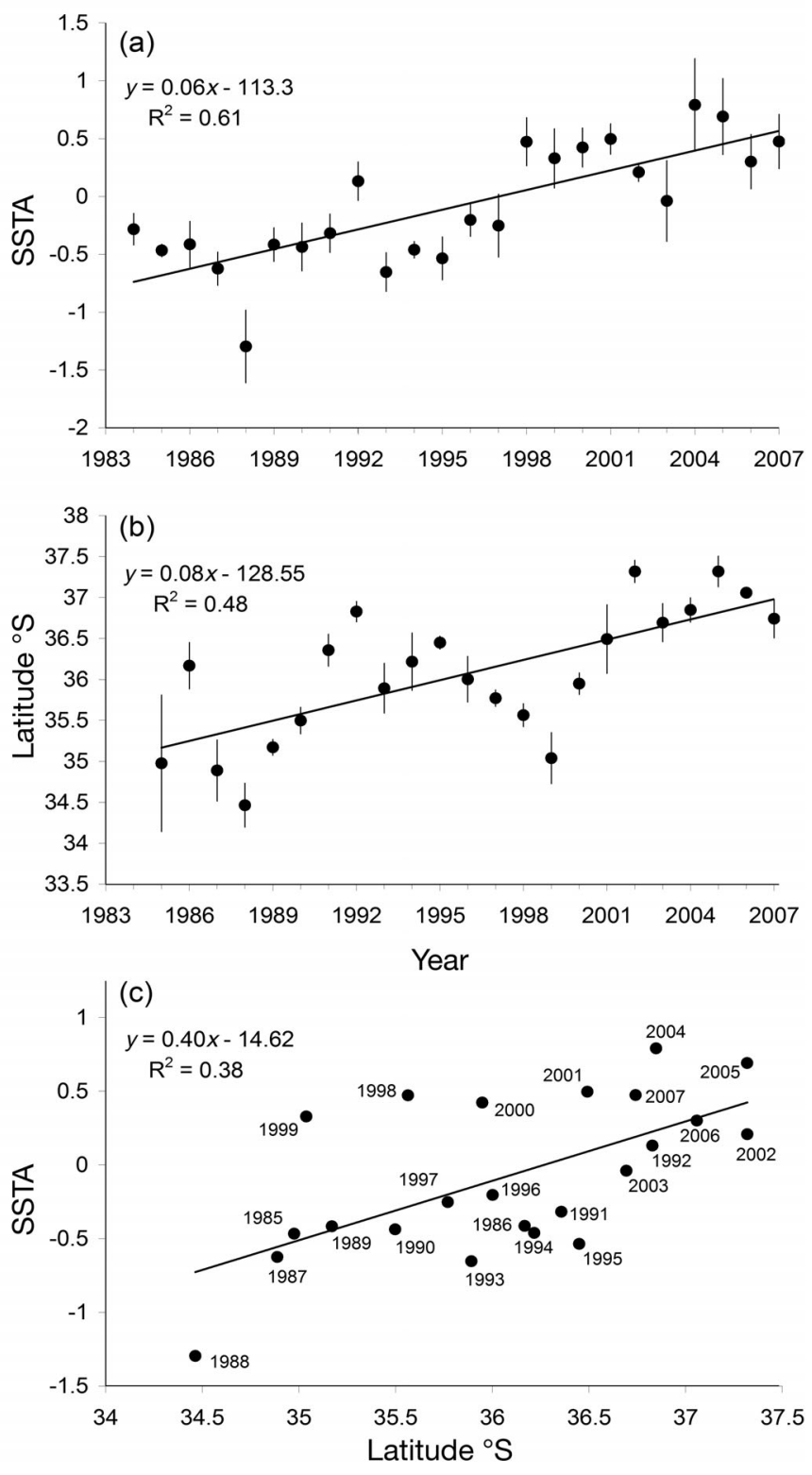

Fig. 2. Long term variations (annual mean $\pm \mathrm{SD}$ ) in (a) sea surface temperature anomaly (SSTA) and (b) the latitudinal position of the $20^{\circ} \mathrm{C}$ isotherm in the South Atlantic Ocean. (c) Relationship between SSTA and the position of the $20^{\circ} \mathrm{C}$ isotherm. All regressions significant $(p<0.001)$

lative sum plot of SSTA (Fig. S2 in the Supplement), which denoted a climate shift after 1997. This declining pattern in abundance was consistently observed for adults (Fig. 3b) and recruits (Fig. 3c). In particular, adult abundance did not recover after the mass mortality events that occurred since the mid 1990s.

The long-term analysis of LFDs showed marked differences between cool and warm years (Fig. 4a). In cool years and before mass mortalities occurred, the yellow clam showed polymodal size structures 

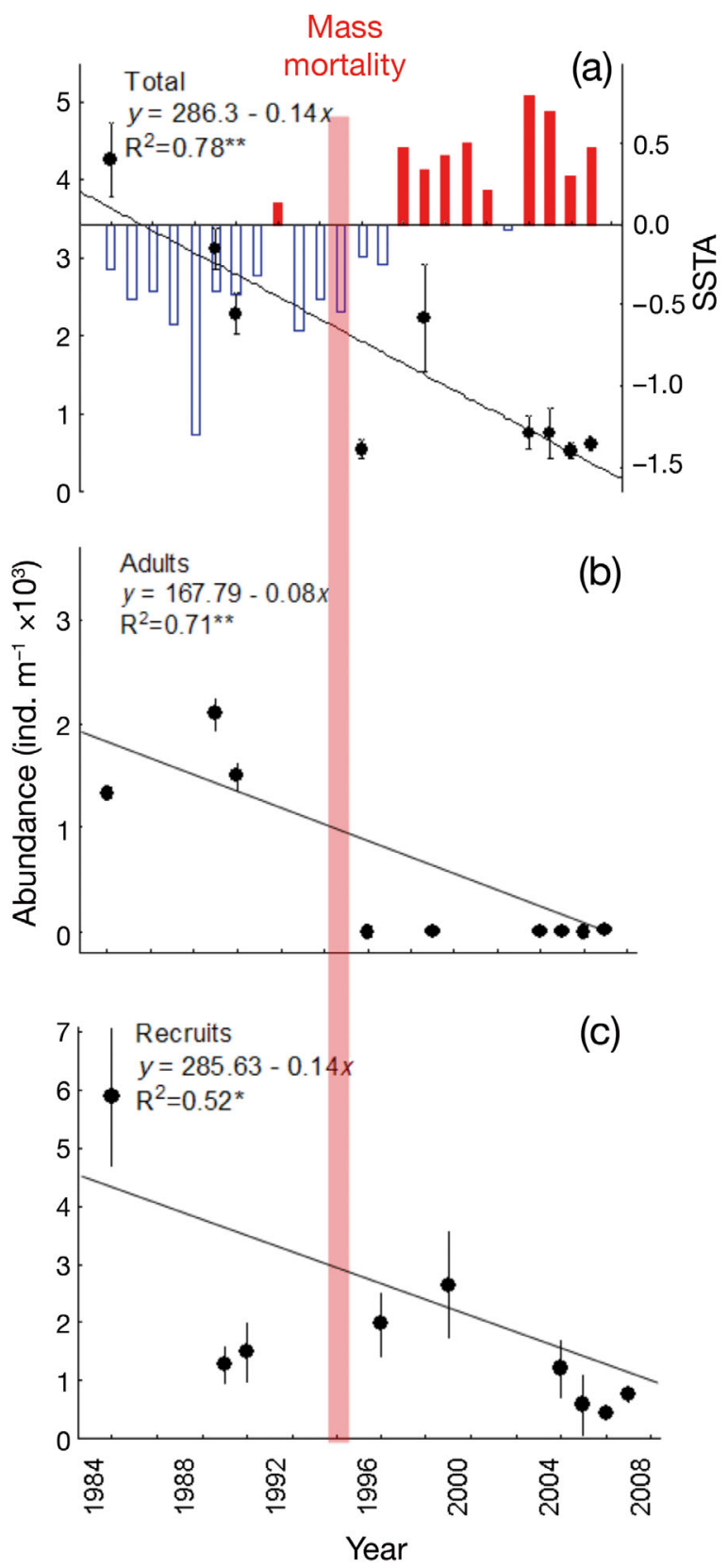

Fig. 3. Mesodesma mactroides. Long-term fluctuations in abundance (mean \pm SE): (a) total population; (b) adults; and (c) recruits. In (a), concurrent variations in sea surface temperature anomaly (SSTA) (1984-2007) are also shown, highlighting cool and warm years. Asterisks indicate significant trends $\left({ }^{* *} \mathrm{p}<0.01,{ }^{*} \mathrm{p}<0.05\right)$

with fully represented population components (years 1984, 1989 and 1990 in Fig. 4a), denoting successful annual recruitments. Conversely, LFDs estimated after the occurrence of mass mortalities (mostly for warm years) scattered thinly with fewer size classes occurring irregularly in time, when larger clams were virtually absent (years 1996, 1999 and 20042007 in Fig. 4a). Consequently, IRSC values decreased linearly through time from 1.00 in 1984 to 0.68 in 2006 and 2007 (Fig. 4b). In 2007 (end of the study period) almost no reproductively active yellow clam individuals were found. The weighted mean individual yellow clam size, estimated as the product of the mean individual size for a given year and the corresponding IRSC estimate, significantly decreased ca. $20 \mathrm{~mm}$ from cool (mean $=27.12 \mathrm{~mm}$ ) to warm $($ mean $=6.86 \mathrm{~mm})$ years, displaying a negative exponential relationship with SSTA (Fig. 5). This trend means smallest individual yellow clam sizes at the end of the study period.

\section{Third prediction: body abnormalities in clams increased over time, concurrently with temperature}

Examination of clams showed that foot and gills presented several abnormalities (Fig. 6a): (1) weak muscular pale areas of foot, which occupied up to $50 \%$ of the total area in $15 \%$ of the clams examined; (2) muscular foot malformations and lesions $(9 \%)$; and (3) amputations or differential thickening of gills $(5 \%)$. Even though clam valves showed no morphological abnormalities, capsules with embryos of Acoela (Turbellaria) adhering to the valve surface were found (Fig. S3a in the Supplement). The prevalence of these capsules increased sharply through time, from $1.1 \%$ in 1990 to $52.4 \%$ in 2007 . As a result of the abovementioned trends, abnormalities (pooled) significantly increased during the 24 yr analyzed, and this increasing trend was particularly noticeable between 2004 and 2007, at the end of the study period (Fig. 6b). The relative occurrence of abnormalities was linearly related with SSTA (Fig. 6c). The analysis discriminated by body abnormality showed the epibiont load as the major driver in the overall pattern observed in pooled data, displaying a positive linear statistically significant relationship with SSTA (Fig. S3b).

\section{DISCUSSION}

This long-term study provides, for the first time, quantitative evidence supporting a long-term effect of climate change on a sandy beach population. Long-term observations revealed significant and consistent associations between SST and yellow clam population responses. Different lines of evidence in 


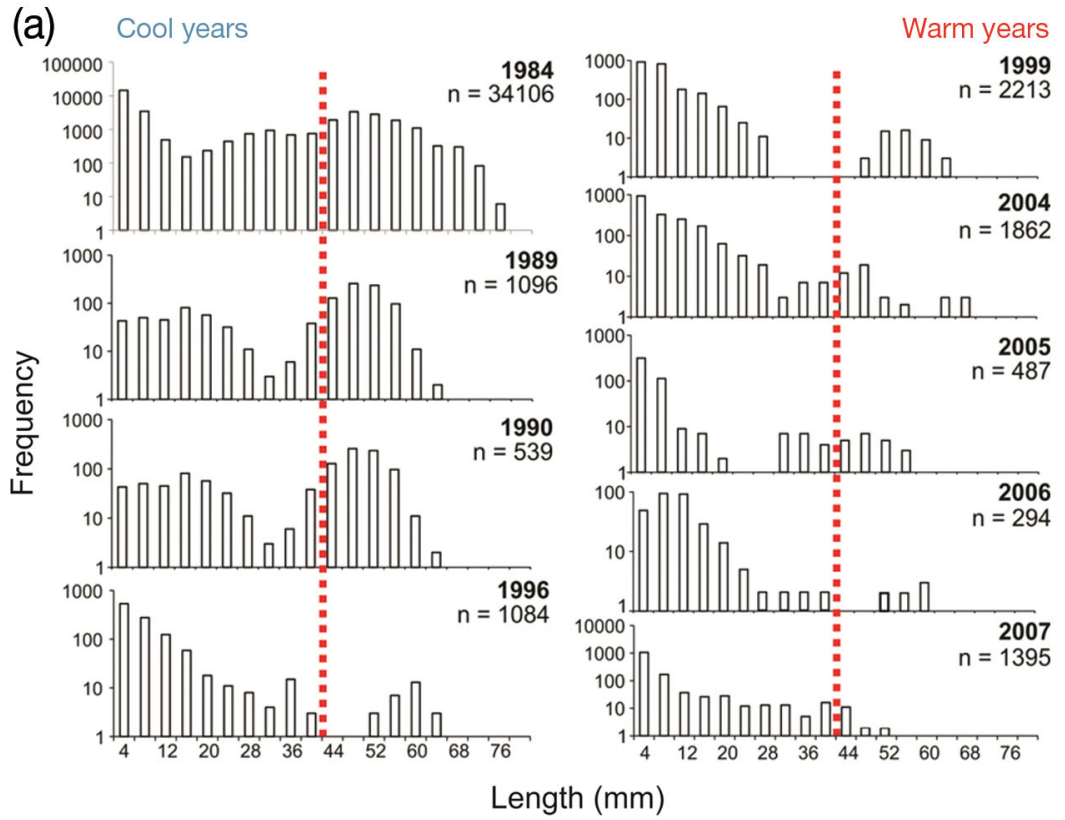

(b)

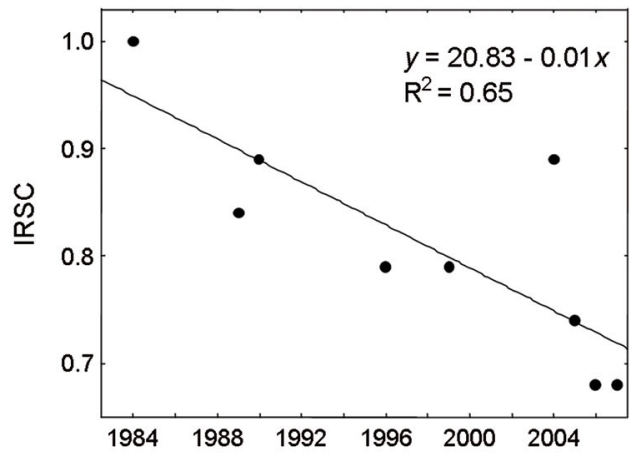

Fig. 4. Mesodesma mactroides. (a) Length-frequency distributions (logarithmic scale) for the period 1984-2007, discriminated by cool and warm years. Dotted lines denote the adult component of the population, given by the mean size at maturity (43 mm) defined by histological analysis according to Masello \& Defeo (1986). (b) Linear decreasing trend in the annual index of recurrence of size classes (IRSC) through time (significant at $\mathrm{p}<0.01$ )

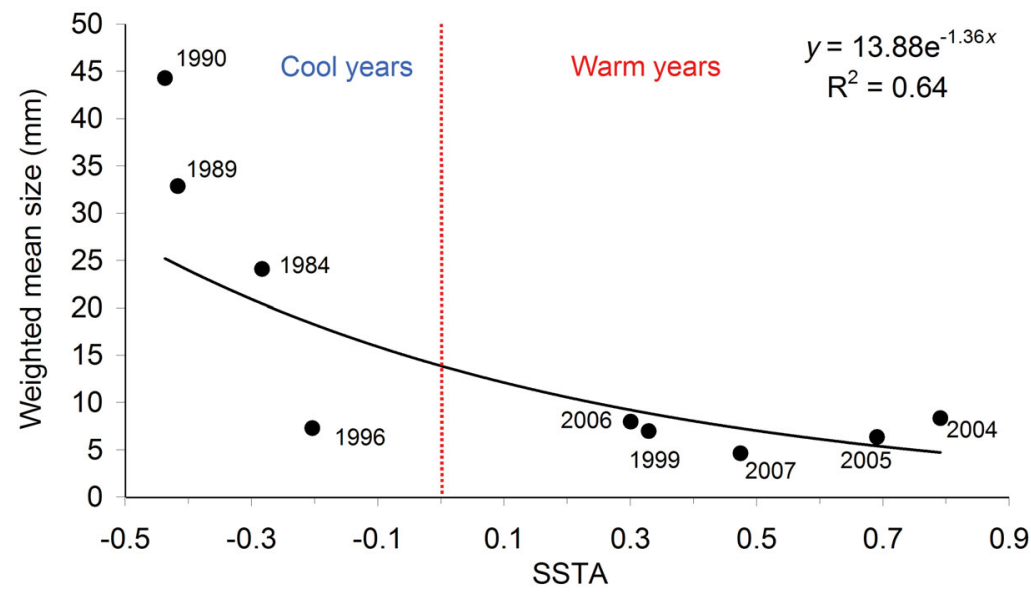

Fig. 5. Mesodesma mactroides. Long-term (1984-2007) relationship between estimated weighted mean individual size (product of the mean individual size for a given year and the corresponding index of recurrence of size classes) and sea surface temperature anomaly (SSTA). Regression is significant $(\mathrm{p}<0.05)$

the environment and in demographic and health features of the yellow clam suggest that climate change could be considered as causal agent of the main changes observed in the last decades.

We showed a systematic long-term increase in SST in the SAO, reflected in a steady poleward shift of the warm water front. This long-term poleward shift of warm water front was on the order of $9 \mathrm{~km} \mathrm{yr}^{-1}$, similar to that found for the North Atlantic, at mid lati- tudes (7.5-15 $\mathrm{km} \mathrm{yr}^{-1}$; Taboada \& Anadón 2012). The positive correlation between SSTA and the latitudinal position of the warm water front suggests that warming may also be related to changes in circulation patterns. In fact, the shift from a cold to a warm phase during the 1990s, as well as the increase in speed and frequency of onshore (southeast) winds (Escobar et al. 2004, Bischoff 2005, Ortega et al. 2013), enhanced the advection of warm waters from the Brazil Current in the northeast Uruguayan slope. This climate change scenario given by the prevalence of warm oligotrophic waters, higher stratification and a decrease in primary productivity (Behrenfeld et al. 2006, Lewandowska et al. 2014) could also have affected food availability and quality for the yellow clam, aggravated by the increasing occurrence of potential outbreaks of harmful algal blooms (Peperzak 2003, Moore et al. 2008) and the higher metabolic clam rates resulting from increasing SST.

Our results suggest that the $\mathrm{SAO}$ is vulnerable to a steady warming scenario. The SAO is a warm-temperate biogeographic province where coastal sys- 

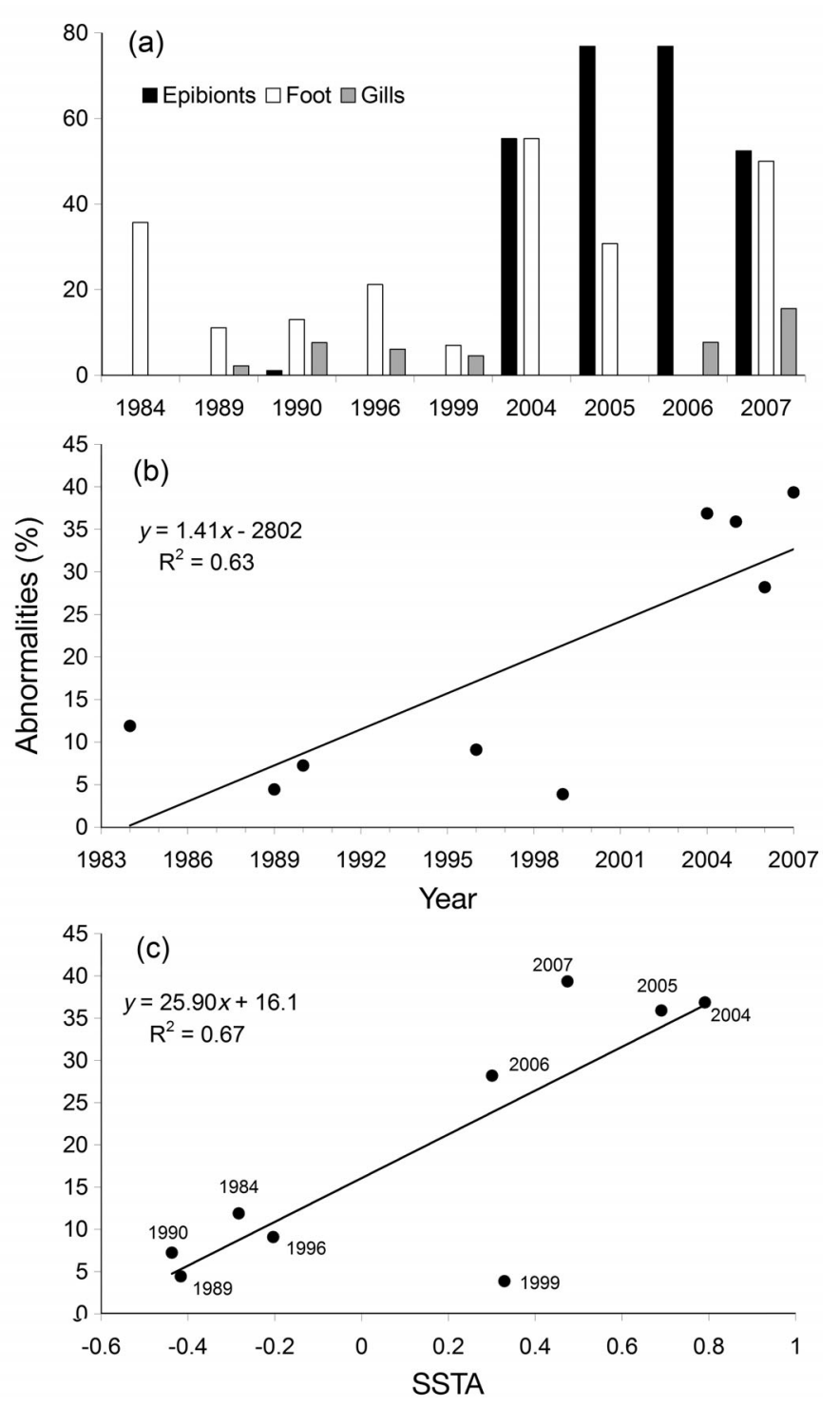

Fig. 6. Mesodesma mactroides. (a) Percentage of body abnormalities discriminated by affected organ, including the occurrence of epibionts (Acoela embryos in the valves); (b) temporal variations in abnormalities (data pooled); and (c) relationship between the relative occurrence of abnormalities and sea surface temperature anomaly (SSTA). Both regressions significant $(p<0.001)$

tems are biodiversity hotspots with high resilience to the usual cyclic oscillations in oceanographic conditions (Horta e Costa et al. 2014). However, the seasonal increase of SSTA in the late 1990s and the current unprecedented changes in composition and structure of ecological assemblages, including range extensions, increasing frequency of records of species with tropical affinities (Demicheli et al. 2006, Segura et al. 2009, Martínez et al. 2009) and shifts in dominance from cool-water species to warm-tem- perate species (Schoeman et al. 2014), reinforce the hypothesis that the SAO system and its biota are responding consistently with expectations under climate change.

Yellow clam abundance (total and discriminated by adults and recruits) decreased through time and was inversely related to long-term variations in SSTA, meaning higher abundance during cold periods. The yellow clam population was sensitive to deteriorating environmental conditions, as illustrated by its systematic decline in abundance concurrently with increasing temperatures, particularly after the beginning of the climate shift in the mid-1990s (Ortega et al. 2013). This climate shift and the warming associated therewith were accompanied by an increase in storm frequency and in the frequency and intensity of onshore winds, which augmented beach erosion rates (Ortega et al. 2013). These adverse climatic conditions probably triggered mass mortalities, which sequentially occurred in a north-south direction (Odebrecht et al. 1995, Fiori \& Cazzaniga 1999, Ortega et al. 2012, Defeo et al. 2013), following increasing SST and the poleward movement of the warm water front documented in this study. Furthermore, these mass mortalities took place concurrently with higher spring and summer temperatures (Fiori et al. 2004).

In Uruguay, mass mortality events that began in late 1994 led to closure of the fishery until 2008, and no evidence of stock recovery was observed throughout this period (Ortega et al. 2012). Immediately before the occurrence of mass mortalities (years 19901994), the fishery was governed by a co-management mode and a set of operational precautionary measures that assured low harvesting levels (Defeo 1996, 1998, Defeo et al. 2016). Therefore, fishing pressure could not be invoked as a putative factor of the observed trends, as in other cases when the concurrent effects of climate and harvesting have been observed (e.g. Planque et al. 2010). Thus, the yellow clam showed a low adaptive capacity to respond to the changing climate, and 3 main constraints could account for this low resilience (Schoeman et al. 2014): (1) its restricted intertidal habitat, which is limited to a narrow fringe of sand between terrestrial and marine systems; (2) the absence of spatial refugia for this obligate beach specialist; and (3) the alignment of beaches in the SAO almost orthogonally to temperature isoclines, which implies strong thermal gradients along the shoreline. Similar patterns were found in the congeneric Mesodesma donacium on the Pacific coasts of Peru and northern Chile, where mass mortality events consistently followed warm El Niño 
Southern Oscillation events in the Pacific (Riascos et al. 2009b, Ortega et al. 2012, Defeo et al. 2013). The higher occurrence of population extirpations along the northern (trailing) range boundary is consistent with expectations under recent climate trends (Ortega et al. 2012). Moreover, the decline in abundance of yellow clam promoted an increase of warmth-favouring species, such as the wedge clam Donax hanleyanus and the mole crab Emerita brasiliensis, which are subordinate competitors for space and food in this suspension-feeding guild (Defeo 2003). This shift has been observed in sandy beach ecosystems in southern Brazil, Uruguay (Defeo 2003), and Argentina (Dadón 2005, Herrmann et al. 2009, Thompson \& Sánchez De Bock 2009).

The systematic decrease in abundance and individual size composition related to increasing temperatures could also have affected the reproductive potential of the species. Indeed, the adult component of the clam population decreased over time, leading to fewer size classes, and large clams were virtually absent at the end of the study period. The decrease in mean size and its relation to warming resemble lifehistory traits of the yellow clam described for the northernmost (trailing) edge of its distribution range, where abundance, individual size and longevity are significantly lower than in southern populations (Fiori \& Defeo 2006). Those authors showed that variations in SST explained large-scale differences in the demography and population dynamics of the yellow clam. Therefore, the sustained increase in SST could have shifted life-history traits of the yellow clam in the centre of its distribution range towards northern distribution characteristics, which is also consistent with expectations under climate change (Burrows et al. 2011, Parmesan et al. 2013, Poloczanska et al. 2013, Schoeman et al. 2014, Caruso et al. 2014). As reduction in body size is a major response to climate change, smaller sized yellow clam individuals could potentially reduce energy transfer rates through food webs and could lead to changes in ecosystem structure and function (Jones et al. 2014).

The long-term analysis of body abnormalities showed that $M$. mactroides has been increasingly affected through time. The increasing SSTA trend and its positive correlation with the relative representation of body abnormalities suggest a link with climate stress. The increase in their prevalence through time could therefore be associated with adverse environmental conditions (Riascos et al. 2011). In addition, the parasite Paravortex mesodesma was reported inside the ducts of the digestive glands of the yellow clam (Brusa et al. 2006), and could be considered as another indicator of stress. Parasites and necrosis in gills and stomachs were also found during mass mortality events in Argentina (Cremonte \& Figueras 2004, Fiori et al. 2004) and in the congeneric Mesodesma donacium in its northernmost (trailing) edge of its distribution range in Pacific coasts (Riascos et al. 2011).

We identified Acoela heavily covering yellow clam valves and the edge of the mantle, constituting the main driver of long-term variations in body abnormalities. Epibiosis could potentially affect digging capacity and hinder the ability to close the valves, thus making the yellow clam more vulnerable to predators and climatic factors. Epibionts reduce the ability of sandy beach macrofauna to escape from predators by increasing mass, reducing motility, and ultimately prolonging the burrowing time during the tidal migration (Villegas et al. 2006, Firstater et al. 2009). Therefore, the yellow clam seems to be affected by a combined effect of increasing SST and an increasing prevalence of body abnormalities (notably epibionts), particularly in early 2000, a few years after the climate shift (Ortega et al. 2013). Similar findings were described in the congeneric Mesodesma donacium: a lower body condition index was related to the level of infestation by a parasitic polychaete that increased its prevalence under increasing temperatures during a warm El Niño phase (Riascos et al. 2009a).

In summary, our analysis showed a significant decrease in abundance and individual size of the yellow clam $M$. mactroides in Uruguay, concurrently with an increase in body abnormalities. All these indicators showed a significant relationship with warming, reflected in a poleward shift in the position of the $20^{\circ} \mathrm{C}$ isotherm and increasing SSTA from 1985 to 2007. The Uruguayan yellow clam population seems to be vulnerable to climate change, as reflected by a high sensitivity (degree to which the probability of persistence of an ecological entity is likely to alter if exposed to a change in climate, sensu Schoeman et al. 2014) to increasing SST and a poor adaptive capacity to respond to these changes. This poor adaptive capacity of the species could be related to its biology and life history traits (e.g. ectotherm with reduced motility), its specificity in habitat selection (e.g. dissipative beaches with a gentle slope and fine grain size) and its Antarctic origin. Our results demonstrate the implications of climate change in the structure of sandy beach fauna, which could be particularly relevant in ectotherms with cold water affinities. Thus, the effects of climate change should be given a high priority in sandy beach conservation planning and management. 
Acknowledgements. We express our gratitude to all the people who helped in sampling and laboratory analyses. Dr. R. Lipcius and 3 anonymous referees provided useful comments that substantially improved the manuscript. The financial support provided by CONICYT (FCE 4034), ANII, CSIC (I+D) and The Pew Fellows Program in Marine Conservation is gratefully acknowledged.

\section{LITERATURE CITED}

Baker-Austin C, Trinanes JA, Taylor NGH, Hartnell R, Siitonen A, Martinez-Urtaza J (2013) Emerging Vibrio risk at high latitudes in response to ocean warming. Nat Clim Change 31:73-77

Behrenfeld MJ, O'Malley RT, Siegel D, Sarmiento JL and others (2006) Climate-driven trends in contemporary ocean productivity. Nature 444:752-755

Bischoff S (2005) Sudestadas. In: Barros V, Menéndez A, Nagy G (eds) El cambio climático en el Río de la Plata. UBA, Buenos Aires, p 53-67

Bowden TJ (2008) Modulation of the immune system of fish by their environment. Fish Shellfish Immunol 25:373-383

Brusa F, Ponce de León R, Damborenea C (2006) A new Paravortex (Platyhelminthes: Dalyellioida) endoparasite of Mesodesma mactroides (Bivalvia: Mesodesmatidae) from Uruguay. Parasitol Res 99:566-571

Burreson EM, Ragone Calvo L (1996) Epizootiology of Perkinsus marinus disease of oysters in Chesapeake Bay, with emphasis on data since 1985. J Shellfish Res 15:17-34

Burrows MT, Schoeman DS, Buckley LB, Moore P and others (2011) The pace of shifting climate in marine and terrestrial ecosystems. Science 334:652-655

Caruso NM, Sears MW, Adams DC, Lips KR (2014) Widespread rapid reductions in body size of adult salamanders in response to climate change. Glob Change Biol 20: 1751-1759

Celentano E, Gutiérrez NL, Defeo O (2010) Effects of morphodynamic and estuarine gradients on a sandy beach mole crab demography and distribution: implications for source-sink habitat dynamics. Mar Ecol Prog Ser 398: 193-205

Cremonte F, Figueras A (2004) Parasites as possible cause of mass mortalities of the critically endangered clam Mesodesma mactroides on the Atlantic coast of Argentina. Bull Eur Assoc Fish Pathol 24:166-171

Cremonte F, Figueras A, Burreson EM (2005) A histopathological survey of some commercially exploited bivalve molluscs in northern Patagonia, Argentina. Aquaculture 249:23-33

Dadón JR (2005) Changes in the intertidal community structure after a mass mortality event in sandy beaches of Argentina. Contrib Zool 74:27-39

Defeo O (1996) Experimental management of an exploited sandy beach bivalve population. Rev Chil Hist Nat 69: 605-614

Defeo O (1998) Testing hypotheses on recruitment, growth, and mortality in exploited bivalves: an experimental perspective. Publ Spec Can Sci Halieut Aquat 125:257-264

Defeo O (2003) Marine invertebrate fisheries in sandy beaches: an overview. J Coast Res (Spec Iss) 35:56-65

Defeo O, Rueda M (2002) Spatial structure, sampling design and abundance estimates in sandy beach macroinfauna: some warnings and new perspectives. Mar Biol 140: 1215-1225
Defeo O, Jaramillo E, Lyonnet A (1992a) Community structure and intertidal zonation of the macroinfauna in the Atlantic coast of Uruguay. J Coast Res 8:830-839

> Defeo O, Ortiz E, Castilla JC (1992b) Growth, mortality and recruitment of the yellow clam Mesodesma mactroides in Uruguayan beaches. Mar Biol 114:429-437

> Defeo O, McLachlan A, Schoeman DS, Schlacher TA and others (2009) Threats to sandy beach ecosystems: a review. Estuar Coast Shelf Sci 81:1-12

Defeo O, Castrejón M, Ortega L, Kuhn AM, Gutiérrez NL, Castilla JC (2013) Impacts of climate variability on Latin American small-scale fisheries. Ecol Soc 18:30

Defeo O, Castrejón M, Pérez-Castañeda R, Castilla JC, Gutiérrez NL, Essington TE, Folke C (2016) Co-management in Latin American small-scale shellfisheries: assessment from long-term case studies. Fish Fish 17: 176-192

> Demicheli M, Martínez A, Ortega L, Scarabino F, Maytía S, Demicheli A (2006) Mass stranding of Argonauta nodosa Lightfoot, 1786 (Cephalopoda, Argonautidae) along the Uruguayan coast (southwestern Atlantic). Rev Biol Mar Oceanogr 41:1-7

> Doney SC, Ruckelshaus M, Duffy JE, Barry JP, Chan F (2012) Climate change impacts on marine ecosystems. Ann Rev Mar Sci 4:11-37

Dugan JE, Defeo O, Jaramillo E, Jones AR and others (2010) Give beach ecosystems their day in the sun. Science 329: 1146

Emilson I (1961) The shelf and coastal waters off Southern Brazil. Bol Inst Oceanogr 17:101-112

Escobar G, Vargas W, Bischoff S (2004) Wind tides in the Río de la Plata estuary: meteorological conditions. Int J Climatol 24:1159-1169

Fiedler PC (2002) Environmental change in the eastern tropical Pacific Ocean: review of ENSO and decadal variability. Mar Ecol Prog Ser 244:265-283

> Fiori S, Cazzaniga N (1999) Mass mortality of the yellow clam, Mesodesma mactroides (Bivalvia, Mesodesmatidae) in Monte Hermoso beach, Argentina. Biol Conserv 89:305-309

Fiori S, Defeo O (2006) Biogeographic patterns in life-history traits of the yellow clam, Mesodesma mactroides, in sandy beaches of South America. J Coast Res 22:872-880

Fiori S, Vidal-Martínez V, Simá-Álvarez R, Rodríguez-Canul R, Aguirre-Macedo ML, Defeo O (2004) Field and laboratory observations of the mass mortality of the yellow clam Mesodesma mactroides in South America: the case of Isla del Jabalí, Argentina. J Shellfish Res 23:451-455

Firstater FN, Hidalgo FJ, Lomovasky BJ, Gallegos P, Gamero P, Iribarne OO (2009) Effects of epibiotic Enteromorpha spp. on the mole crab Emerita analoga in the Peruvian central coast. J Mar Biol Assoc UK 89:363-370

Ford SE, Tripp MR (1996) Diseases and defence mechanisms. In: Kennedy VS, Newell RIE, Eble AF (eds) The eastern oyster: Crassostrea virginica. Maryland Sea Grant, College Park, MD, p 581-660

Gianelli I, Martínez G, Defeo O (2015) An ecosystem approach to small-scale co-managed fisheries: the yellow clam fishery in Uruguay. Mar Policy 62:196-202

Harvell CD, Mitchell CE, Ward JR, Altizer S, Dobson AP, Ostfeld RS, Samuel MD (2002) Climate warming and disease risks for terrestrial and marine biota. Science 296: 2158-2162

Herrmann M, Carstensen D, Fischer S, Laudien J, Penchaszadeh PE, Arntz WE (2009) Population structure, growth, 
and production of the wedge clam Donax hanleyanus (Bivalvia: Donacidae) from northern Argentinean beaches. J Shellfish Res 28:511-526

Horta e Costa B, Assis J, Franco G, Erzini K, Henriques M, Gonçalves EJ, Caselle JE (2014) Tropicalization of fish assemblages in temperate biogeographic transition zones. Mar Ecol Prog Ser 504:241-252

> Jones DOB, Yool A, Wei CL, Henson S, Ruhl H, Watson R, Gehlen M (2014) Global reductions in seafloor biomass in response to climate change. Glob Change Biol 20: 1861-1872

Kordas RL, Harley CDG, O'Connor MI (2011) Community ecology in a warming world: the influence of temperature on interspecific interactions in marine systems. J Exp Mar Biol Ecol 400:218-226

> Lercari D, Defeo O (2006) Large-scale diversity and abundance trends in sandy beach macrofauna along full gradients of salinity and morphodynamics. Estuar Coast Shelf Sci 68:27-35

> Lercari D, Defeo O (2015) Large-scale dynamics of sandy beach ecosystems in transitional waters of the Southwestern Atlantic Ocean: species turnover, stability and spatial synchrony. Estuar Coast Shelf Sci 154:184-193

Lewandowska AM, Boyce DG, Hofmann M, Matthiessen B, Sommer U, Worm B (2014) Effects of sea surface warming on marine plankton. Ecol Lett 17:614-623

Loreau M, Roy J, Tilman D (2005) Linking ecosystem and parasite ecology. In: Thomas F, Guégan JF, Renaud F (eds) Parasitism and ecosystems. Oxford University Press, Oxford, p 13-21

> Margolis L, Esch GW, Holmes JC, Kuris AM, Schad GA (1982) The use of ecological terms in parasitology (report of an ad hoc committee of the American Society of Parasitologists). J Parasitol 68:131-133

Marins LF, Levy JA (1999) High genetic distance between marine bivalves of the genus Mesodesma inhabiting the Atlantic and Pacific coasts of South America. Comp Biochem Physiol A 124:313-319

Martínez G, Scarabino F, Delgado E (2009) New records of the brachyuran crabs Hepatus pudibundus (Aethridae) and Persephona mediterranea (Leucosiidae) in their southernmost Western Atlantic distribution. J Aquat Sci 4:279-282

Masello A, Defeo O (1986) Determinación de la longitud de primera madurez sexual en Mesodesma mactroides (Deshayes 1854). Comun Soc Malacol Urug VI:387-392

Maynard J, van Hooidonk R, Mark Eakin C, Puotinen M and others (2015) Projections of climate conditions that increase coral disease susceptibility and pathogen abundance and virulence. Nat Clim Change 5:688-694

McLachlan A, Dugan JE, Defeo O, Ansell AD, Hubbard DM, Jaramillo E, Penchaszadeh P (1996) Beach clam fisheries. Oceanogr Mar Biol Annu Rev 34:163-232

McLachlan A, Defeo O, Jaramillo E, Short AD (2013) Sandy beach conservation and recreation: guidelines for optimising management strategies for multipurpose use. Ocean Coast Manage 71:256-268

> Moore SK, Trainer VL, Mantua NJ, Parker MS, Laws E, Backer LC, Fleming LE (2008) Impacts of climate variability and future climate change on harmful algal blooms and human health. Environ Health 7 (Suppl 2):S4

Nye JA, Link JS, Hare JA, Overholtz WJ (2009) Changing spatial distribution of fish stocks in relation to climate and population size on the Northeast United States continental shelf. Mar Ecol Prog Ser 393:111-119
Odebrecht C, Rodrig L, Garcia VT, Abreau PC (1995) Shellfish mortality and a red tide event in southern Brazil. In: Lassus P, Arzul G, Erard E, Gentien P, Marcaillou C (eds) Harmful marine algal blooms. Lavoisier Intercept, Paris p 213-218

Ortega L, Castilla JC, Espino M, Yamashiro C, Defeo O (2012) Effects of fishing, market price, and climate on two South American clam species. Mar Ecol Prog Ser 469:71-85

> Ortega L, Celentano E, Finkl C, Defeo O (2013) Effects of climate variability on the morphodynamics of Uruguayan sandy beaches. J Coast Res 29:747-755

Parmesan C, Yohe G (2003) A globally coherent fingerprint of climate change impacts across natural systems. Nature 421:37-42

Parmesan C, Burrows MT, Duarte CM, Poloczanska ES, Richardson AJ, Schoeman DS, Singer MC (2013) Beyond climate change attribution in conservation and ecological research. Ecol Lett 16:58-71

> Peperzak L (2003) Climate change and harmful algal blooms in the North Sea. Acta Oecol 24:S139-S144

- Planque B, Fromentin JM, Cury P, Drinkwater KF, Jennings S, Perry RI, Kifani S (2010) How does fishing alter marine populations and ecosystems sensitivity to climate? J Mar Syst 79:403-417

> Poloczanska ES, Brown CJ, Sydeman WJ, Kiessling W and others (2013) Global imprint of climate change on marine life. Nat Clim Change 3:919-925

R Development Core Team (2008) R: a language and environment for statistical computing. R Foundation for Statistical Computing, Vienna. www.R-project.org

Reynolds RW, Rayner NA, Smith TM, Stokes DC, Wang W (2002) An improved in situ and satellite SST analysis for climate. J Clim 15:1609-1625

Riascos JM, Guzmán N, Laudien J, Oliva ME, Heilmayer O, Ortlieb L (2009a) Long-term parasitic association between the boring polychaete Polydora bioccipitalis and Mesodesma donacium. Dis Aquat Org 85:209-215

Riascos JM, Carstensen D, Laudien J, Arntz WE, Oliva ME, Güntner A, Heilmayer O (2009b) Thriving and declining: climate variability shaping life-history and population persistence of Mesodesma donacium in the Humboldt Upwelling System. Mar Ecol Prog Ser 385:151-163

Riascos JM, Heilmayer O, Oliva ME, Laudien J (2011) Environmental stress and parasitism as drivers of population dynamics of Mesodesma donacium at its northern biogeographic range. ICES J Mar Sci 68:823-833

Schlacher TA, Dugan J, Schoeman DS, Lastra M and others (2007) Sandy beaches at the brink. Divers Distrib 13: $556-560$

Schlacher TA, Schoeman DS, Dugan J, Lastra M, Jones A, Scapini F, McLachlan A (2008) Sandy beach ecosystems: key features, sampling issues, management challenges and climate change impacts. Mar Ecol 29:70-90

- Schoeman DS, Schlacher TA, Defeo O (2014) Climatechange impacts on sandy-beach biota: crossing a line in the sand. Glob Change Biol 20:2383-2392

Segura AM, Carranza A, Rubio LE, Ortega L, García M (2009) Stellifer rastrifer (Pisces: Sciaenidae): first Uruguayan records and a $1200 \mathrm{~km}$ range extension. Mar Biodivers Rec 2:e67

Taboada FG, Anadón R (2012) Patterns of change in sea surface temperature in the North Atlantic during the last three decades: beyond mean trends. Clim Change 115: 419-431 
Thompson GA, Sánchez De Bock MA (2009) Influence of beach morphodynamics on the bivalve Donax hanleyanus and Mesodesma mactroides populations in Argentina. Mar Ecol 30:198-211

Thomsen H (1962) Masas de agua características del Océano Atlántico (parte Sudoeste). Servicio de Hidrografía Naval Publ H632, Secretaría Marina, Buenos Aires

Travers MA, Basuyaux O, LeGoic N, Huchette S, Nicolas JL, Koken M, Paillard C (2009) Influence of temperature and spawning effort on Haliotis tuberculata mortalities caused by Vibrio harveyi: an example of emerging vibriosis linked to global warming. Glob Change Biol 15: 1365-1376

Editorial responsibility: Romuald Lipcius, Gloucester Point, Virginia, USA
Uribe RA, Oliva ME, Aguilar S, Yamashiro C, Riascos JM (2012) Latitudinal variation in the reproductive cycle of two bivalves with contrasting biogeographical origin along the Humboldt Current Upwelling Ecosystem. Sci Mar 76:713-720

Villegas MJ, Stotz W, Laudien J (2006) First record of an epibiosis between the sand crab Emerita analoga (Stimpson, 1857) (Decapoda: Hippidae) and the mussel Semimytilus algosus (Gould, 1850) (Bivalvia, Mytilidae) in Southern Peru. Helgol Mar Res 60:25-31

Von Ihering H (1907) Les mollusques fossils du tertiare et du crétacé supérieur de l'Árgentine. An Mus Nac Buenos Aires 7(3 Ser):1-611

Submitted: August 5, 2015; Accepted: January 31, 2016 Proofs received from author(s): February 26, 2016 